\title{
Can a one-sampling campaign produce robust results for water quality monitoring? A case of study in Itupararanga reservoir, SP, Brazil
}

\author{
Estudos baseados em uma única campanha de amostragem podem produzir resultados \\ robustos para o monitoramento da qualidade da água? Um estudo de caso no \\ reservatório de Itupararanga, SP, Brasil
}

Frederico Guilherme de Souza Beghelli1*, Marcelo Luiz Martins Pompề ${ }^{2}$, Mônica Páscoli, Vivian Silva Lira ${ }^{1}$, Renata de Lima ${ }^{3}$ and Viviane Moschini-Carlos ${ }^{1}$

\author{
${ }^{1}$ Universidade Estadual Paulista - UNESP, Avenida Três de Março, 511, Alto da Boa Vista, \\ CEP 18087-180, Sorocaba, SP, Brazil \\ ${ }^{2}$ Departamento de Ecologia Instituto de Biologia - IB, Universidade de São Paulo - USP, \\ Rua do Matão, Travessa 14, 321, Butantã, CEP 05508-090, São Paulo, SP, Brazil \\ ${ }^{3}$ Universidade de Sorocaba - UNISO, Rodovia Raposo Tavares, Km 92,5, Artura, CEP 18023-000, \\ Sorocaba, SP, Brazil \\ *e-mail: fred_sb@hotmail.com
}

Cite as: Beghelli, F.G.S. et al. Can a one-sampling campaign produce robust results for water quality monitoring? A case of study in Itupararanga reservoir, SP, Brazil. Acta Limnologica Brasiliensia, 2016, vol. 28, e6.

\begin{abstract}
Aim: The aim of this study was to conduct a rapid and comprehensive analysis of the reservoir using physical, chemical and biological variables comprising water and sediment as also to verify if a one-sampling campaign can produce information that is robust enough for monitoring purposes. Methods: One-sampling campaign was performed along the central body of Itupararanga reservoir comprising five sampling points. The following physico-chemical and biological variables were measured in each of them from water samples: temperature, $\mathrm{pH}$, concentration of dissolved oxygen, electric conductivity, suspended matter, total nitrogen and phosphorus and fecal coliforms. A genotoxicity assay with Allium cepa was also performed with water from each one of the five sampling points. As a complement, the phytoplankton and benthic macroinvertebrates communities were also analyzed in the two most distant sampling points (P1 and P5). Results: Results indicate a scenario with eutrophication and toxicity. High concentrations of fecal coliforms were recorded and there is a worrying prevalence of cyanobacteria - potential toxin producers - in phytoplankton community. Benthic macroinvertebrates analysis suggests poor quality of the water and sediments. Genotoxicity tests suggest the presence of toxic substances along the waterbody. Conclusions: It is concluded that Itupararanga reservoir has water with poor quality that could be related to the land uses around the reservoir. The comprehensive approach performed here - where distinct sources of monitoring variables was considered - despite the rapid protocol (one campaign), was enough to respond to the distinct anthropic impacts received by the reservoir. Considering it, this approach is recommended as a rapid diagnostic tool.
\end{abstract}

Keywords: water quality monitoring; bioindicator; biomonitoring; neurotoxins; hepatotoxins.

Resumo: Objetivo: O objetivo deste estudo foi realizar uma análise rápida e abrangente do reservatório usando variáveis físicas, químicas e biológicas, compreendendo água e sedimento e verificar se esta abordagem baseada em uma única campanha de coleta pode fornecer informaçóes suficientemente robustas para o monitoramento. Métodos: Uma campanha de amostragem foi realizada ao longo do corpo central do reservatório de Itupararanga compreendendo cinco pontos de 
amostragem. As seguintes variáveis biológicas e físico-químicas foram determinadas em cada ponto a partir de amostras de água: temperatura, $\mathrm{pH}$, concentração de oxigênio dissolvido, condutividade elétrica, material em suspensão, nitrogênio e fósforo totais e coliformes fecais. Um ensaio de genotoxicidade com Allium cepa também foi realizado com água proveniente de cada um dos cinco pontos de amostragem. Como complemento, as comunidades fitoplanctônica e de macroinvertebrados bentônicos também foram analisadas, mas apenas nos dois pontos de amostragem mais extremos (P1 e P5). Resultados: Os resultados indicam um cenário de eutrofização e toxicidade. Altas concentraçóes de coliformes fecais foram registradas e há uma prevalência preocupante de cianobactérias - potenciais produtoras de toxinas - no fitoplâncton. A análise dos macroinvertebrados bentônicos indica baixa qualidade da água e dos sedimentos. Os testes de genotoxicidade sugerem a presença de substâncias tóxicas ao longo do corpo d'água. Conclusóes: Conclui-se que as águas do reservatório de Itupararanga apresentam baixa qualidade. Tal situaçáo pôde ser relacionada aos usos do solo no entorno do reservatório. A abordagem abrangente ora realizada onde fontes distintas de variáveis para monitoramento foram consideradas, apesar do protocolo expedito (uma campanha), foi suficiente para responder aos diferentes tipos de impactos antrópicos recebidos pelo reservatório sendo uma opção viável para um diagnóstico rápido.

Palavras-chave: monitoramento da qualidade da água; bioindicadores; biomonitoramento; neurotoxinas; hepatotoxinas.

\section{Introduction}

The water bodies provide many services for humanity but the misusage of them or of the surroundings can seriously compromise water quality and availability (Cunha et al., 2013; Suriano \& Fonseca-Gessner, 2013; Silva \& Costa, 2015). Some of the most widespread impacts are: riparian forestry removal (Torres \& Ramirez, 2014); the contamination promoted by agrochemicals (Giraldo et al., 2014; Díaz-Barriga et al., 2015), industrial and domestic wastes (Maceda-Veiga et al., 2013) as also the exotic species introduction (Beghelli et al., 2014a; Fernandez et al., 2014; Rietzler et al., 2014). There is a growing number of pollutants detected in different kinds of environments. This situation highlights the requirements for precaution and treatment measures as also for warning for the possible consequences that these substances may cause in the environment and human health (Jongh et al., 2012; Wongsasuluk et al., 2014; Testai et al., 2016). This scenario may be worst when the water body is inserted in an urban area where it may receive many different impacts from multiple sources and where there is high demands for water. In Brazil, some reservoirs as Billings (Moschini-Carlos et al., 2010; Pompêo et al., 2013; Duarte \& Borges, 2016) and Guarapiranga (Fontana et al., 2014) are emblematic situations of urban reservoirs that are seriously damaged by water contamination and surrounding environment misusing.

Once there are many types of anthropic impact and considering the complexity of ecosystems, the environmental assessment must take into account distinct predictors and its interactions. Distinct types of stresses in aquatic environment need the appropriate monitoring tools.

When considering water quality, the main impacts are the eutrophication, usually related to sewage discharges, agriculture and pasture as its consequences as oxygen depletion, bad smell, fish kill and the increase in the probabilities of cyanotoxins release (Vasconcelos, 2015; Beghelli et al., 2016); toxicity caused by metal pollution (Di Veroli et al., 2014; Cardoso-Silva et al., 2016) and organic pollutants (Zelníčková et al., 2015), usually related to industrial activities, urbanization and agriculture.

When considering aquatic ecosystems, vast areas and distinct environments with their own peculiarities must to be monitored but the human and economic resources are limited and the time is a key factor when the objective is the maintenance of the ecosystems. Considering this scenario, monitoring tools and protocols are desirable and they must be the most accurate as possible but at the same time it is also desirable tools with low cost and time consuming.

Among the predictors there are some ones with well-established protocols as the coliforms and eutrophication analyses. The first one is mainly related to sewage discharges or to the entrance of organic matter from livestock (Muniz et al., 2011). The latter is related to the entrance of nutrients in the ecosystems, mainly phosphorus and nitrogen, usually coming from sewage or agriculture activities (Trindade \& Mendonça, 2014; Ni et al., 2015). Other variables as electric conductance, dissolved oxygen, $\mathrm{pH}$, transparency and suspended matter can be related with the problems previously related, but they are also related with the generic conditions of the environment (Muniz et al., 2011; Esteves et al., 2015). 
The biological communities are important tools in environmental assessment once they can integrate the environmental condition in opposition to the physico-chemical analyses, which are more specific. Furthermore, distinct communities have their specific roles in the ecosystems and may present differential sensitivities to pollution (Bonada et al., 2006). Genotoxicological and citotoxicological assays can bring information about toxicity in the environment. These assays can also give information to quantify the degree of toxicity, considering the cellular and chromosomal levels of organization. As consequence, they work as an alert about the risks to the biota or to the human health (Martins et al., 2016; Singleton et al., 2016).

A rapid protocol for environmental diagnosis is proposed in this work, based on the hypothesis that a one-sampling campaign can generate robust information when different types of environmental indicators are considered and compared. To test this, the results from different predictors were compared witch other and with the land uses in an approach based on the weight of evidence (i.e. concordance in results). To do so, in the present work, each result was considered as an evidence that can give support or contradict the others (Lowell et al., 2000; Benedetti et al., 2012; Brandt et al., 2016).
The aim of this work was to take a rapid and comprehensive analysis of the situation of the Itupararanga reservoir and to verify if a one-sampling campaign with distinct indicators are informative for monitoring purposes. For this, physical, chemical and biological analysis were performed.

Study site: The Itupararanga is a tropical reservoir inserted in an urbanized region. It is formed by three main rivers (Figure 1) that form, posteriorly, the Sorocaba River - the main former river of the left margin of Tietê River. The waters from Itupararanga reservoir are used for many purposes as water supply for around a million people, power supply and to the irrigation of crops (Smith et al., 2005). The reservoir also suffers some negative impacts. The surrounding lands had the original vegetation suppressed in a great extension that passed to be occupied for gated communities, small farms and pastures. Sewage discharges, especially in the former rivers are also reported (Manfré et al., 2011; Taniwaki et al., 2013).

\section{Material and Methods}

Samplings and in situ analyses were performed at September 3rd 2013 at five sampling points along the transitional and lacustrine zones of

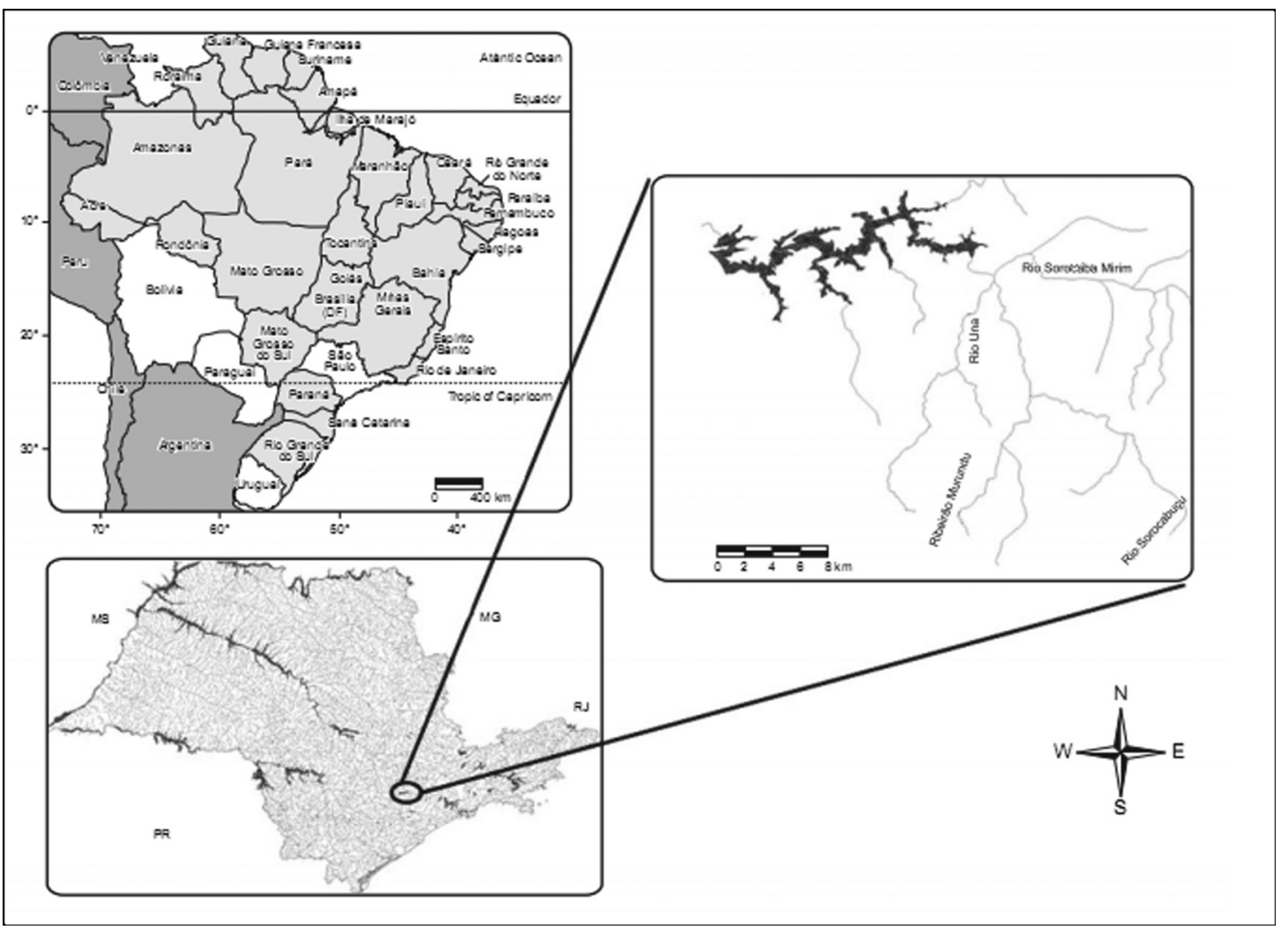

Figure 1. Itupararanga reservoir localization. 
the central body of the reservoir (Beghelli et al., 2012). A schematic map of the reservoir with the localization and geographic coordinates is drawn in Figure 2. The predominant anthropic uses were qualitatively determined based on former researches (Freitas et al., 2008; Manfré et al., 2011; Taniwaki et al., 2013) as also it was based on the interpretation of satellite images and field observations.

Sampling point P1 can be described as an area over intense multiple rural uses, mainly cattle raising, nude soil and eucalyptus plantation. In this area it can be also noticed the lower native vegetation proportion. The P2 is near of the greatest area with natural vegetation. However, the left margin in P2 area is entirely converted for agricultural purposes. Sampling point $\mathrm{P} 3$ area has also the right side well preserved but the left one is mainly occupied by an urbanized zone but in lower intensity then $\mathrm{P} 4$ and $\mathrm{P} 5$. The $\mathrm{P} 4$ and $\mathrm{P} 5$ are in the most urbanized areas along the reservoir wherein $\mathrm{P} 5$ is the one that must receive the greatest pressure from this category of land use (Figure 3).

There were determined physical, chemical and biological variables for water quality characterization in five sampling points in the Itupararanga reservoir.
The performed analysis as also the abbreviations considered for the present work, the method and references are described in Table 1.

As a complement, phytoplankton and benthic macroinvertebrates communities from the first (P1) and last (P5) sampling points were analyzed.

Samples of surface water were collected using nets with a mesh size of $20 \mu \mathrm{m}$ and fixed with formaldehyde (4\%) for qualitative analysis of phytoplankton. For quantitative analysis, raw water samples were fixed with acetic lugol (1\%), and counting was performed by the method described by Utermöhl (1958), using sedimentation chambers and an inverted microscope (Zeiss Axiovert Scope A1). Taxonomic identification was performed until class level according to Bicudo \& Menezes (2006) and Sant'Anna et al. (2006).

Benthic macroinvertebrates were collected by using a Van Veen dredge (area $=0.04 \mathrm{~m} 2$ ). The dredge was launched twice to compose one cumulative sampling per sampling point. Samples were sieved in the field $(0.212 \mathrm{~mm})$ and fixed with formaldehyde $4 \%$. Benthic macroinvertebrates were counted and then identified under optic microscope (Zeiss Scope A1) until subfamily level for Oligochaeta, tribe for Chirnomidae and genus

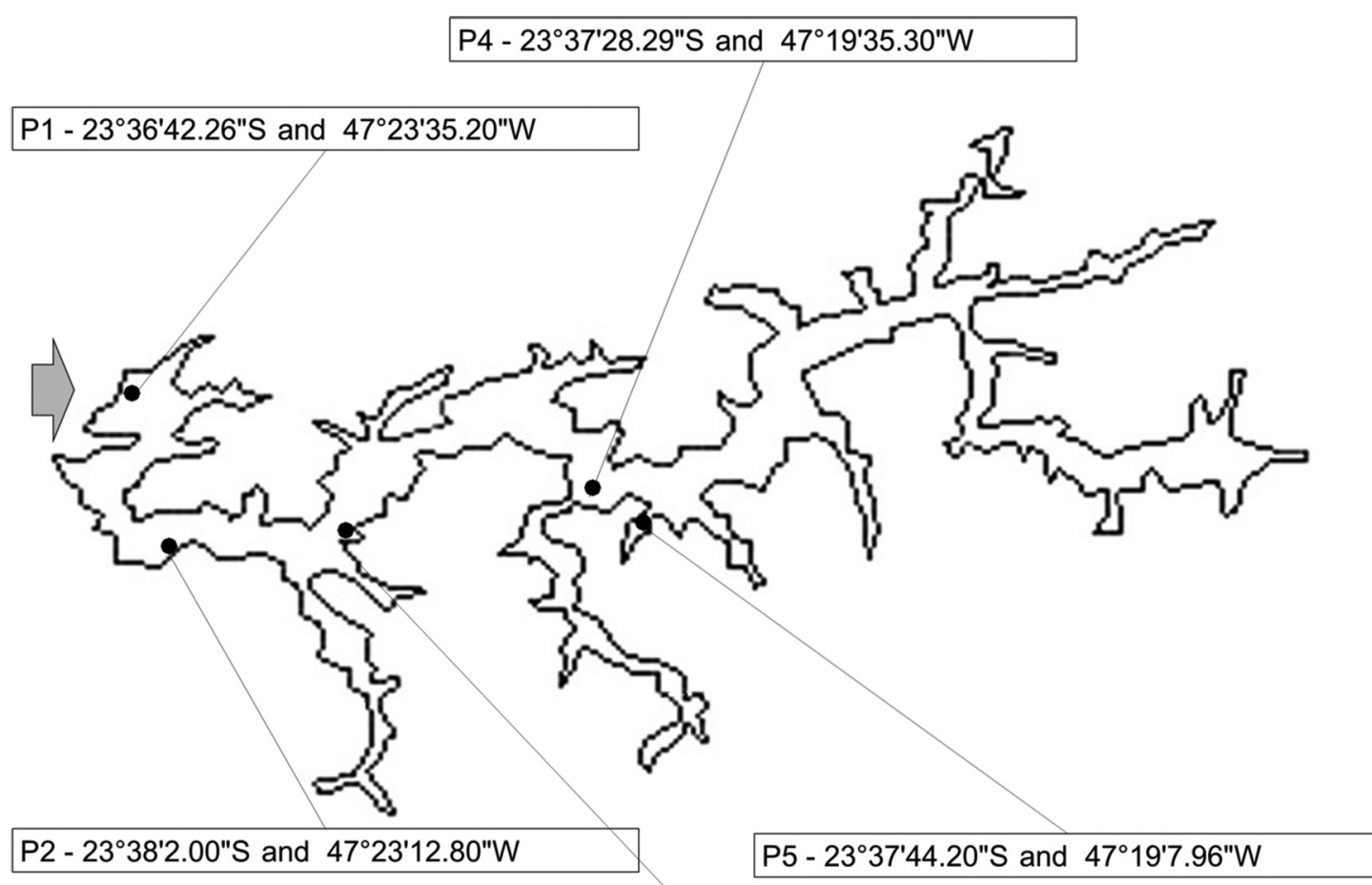

P3 - $23^{\circ} 37^{\prime} 48.99 " S$ and $47^{\circ} 21^{\prime} 41.84 " \mathrm{~W}$

Figure 2. Schematic map of the Itupararanga reservoir showing sampling points. The arrow indicates the approximate dam position in the reservoir. 


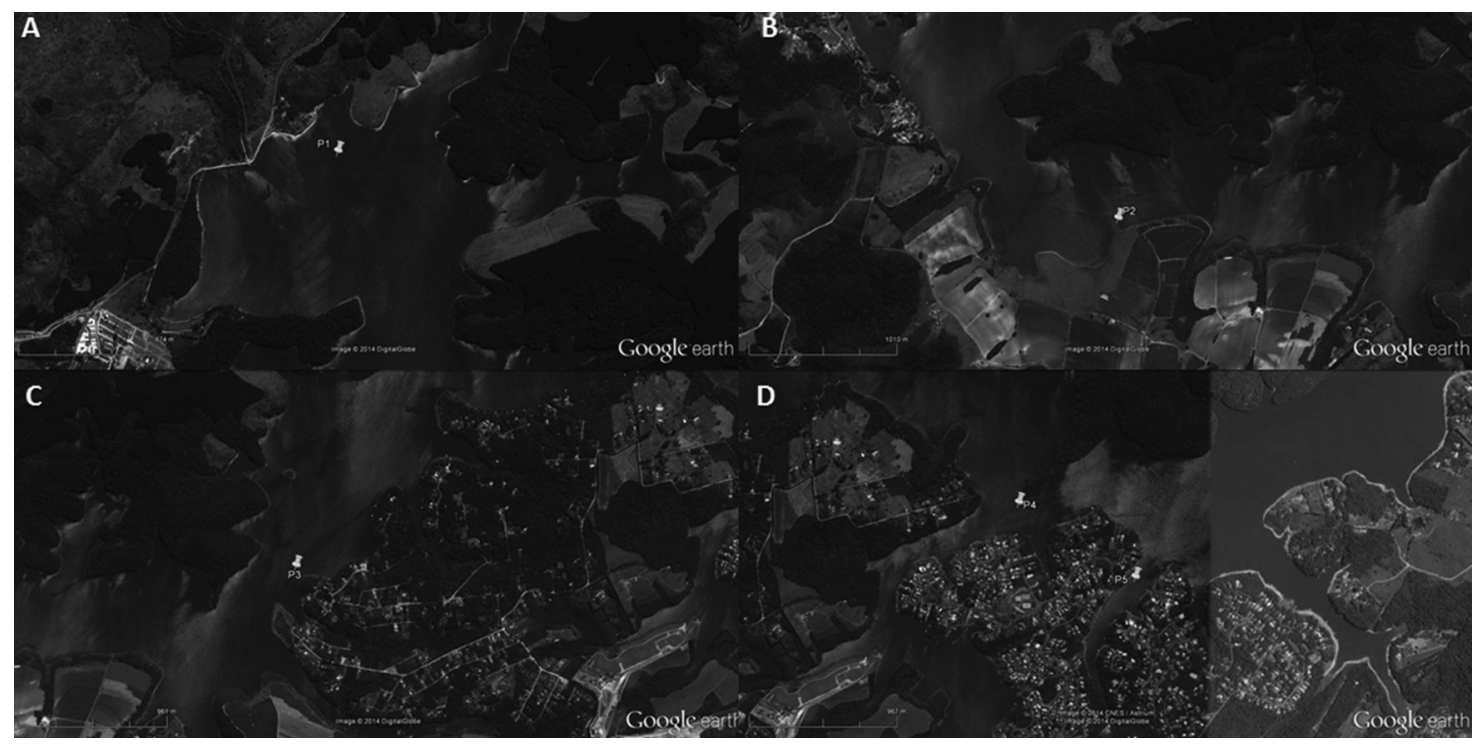

Figure 3. Satellite picture showing land uses around the sampling points: (A) P1; (B) P2; (C) P3; (D) P4 and P5. Source: Google Earth.

Table 1. Variables analyzed, methods and references.

\begin{tabular}{|c|c|c|}
\hline Analysis $^{1}$ & Methods & Reference \\
\hline $\mathrm{pH}$ & Portable phmeter (in situ) & +-------- \\
\hline $\mathrm{EC}\left(\mu \mathrm{S} . \mathrm{cm}^{-1}\right)$ & Portable condutivimeter HI 98304 (DiST ${ }^{\circledR} 4$ ) (in situ) & --------- \\
\hline $\mathrm{DO}\left(\mathrm{mg} \cdot \mathrm{L}^{-1}\right)$ & Titulometria & Winkler (1888) \\
\hline Secchi $(m)$ & Secchi disk & Esteves (2011) \\
\hline $\mathrm{T}\left({ }^{\circ} \mathrm{C}\right)$ & Digital thermometer & --------- \\
\hline $\mathrm{SM} / \mathrm{DM}\left(\mathrm{mg} \cdot \mathrm{L}^{-1}\right)$ & Gravimetric & $\begin{array}{l}\text { Wetzel and Likens (1991), } \\
\text { Paranhos (1996) }\end{array}$ \\
\hline $\mathrm{TN}\left(\mu \mathrm{g} \cdot \mathrm{L}^{-1}\right)$ & Spectrophotometry & $\mathrm{HACH}^{\circledast}$ \\
\hline $\mathrm{TP}\left(\mu \mathrm{g} \cdot \mathrm{L}^{-1}\right)$ & Spectrophotometry & $\mathrm{HACH}^{\circledR}$ \\
\hline Chl-a $\left(\mu g \cdot L^{-1}\right)$ & Spectrophotometry & Wetzel \& Likens (1991) \\
\hline Phyto (ind. $L^{-1}$ ) & $\begin{array}{c}\text { Phytoplankton mesh ( } 0.25 \mu \mathrm{m} \text { opening), } \\
\text { four times dragging. }\end{array}$ & $\begin{array}{l}\text { Wetzel \& Likens (1991) } \\
\text { Utermohl (1958) }\end{array}$ \\
\hline IMMIB & $\begin{array}{l}\text { Two dredging in the littoral region, sieved over } \\
0.2 \mathrm{~mm} \text { mesh opening, multimetric approach. }\end{array}$ & Beghelli et al. (2015) \\
\hline Col (MPN.100mL) & Colorimetric (Colillert - IDEXX Quanti-Tray 2000) & APHA (2005) \\
\hline TSI of Lamparelli & Spectrophotometry & $\begin{array}{l}\text { Beghelli et al. (2012), } \\
\text { Cunha et al. (2013) }\end{array}$ \\
\hline $\mathrm{IM} / \mathrm{IA}$ & Allium cepa & Tedesco \& Laughinghouse (2012) \\
\hline \multicolumn{3}{|c|}{$\begin{array}{l}{ }^{1} \mathbf{E C}=\text { electric conductivity; } \mathbf{D O}=\text { dissolved oxygen; } \text { Secchi }=\text { Secchi disk lecture; } \mathbf{T}=\text { temperature; } \mathbf{S M} / \mathbf{D M}=\text { suspended } \\
\text { matter / dissolved matter; } \mathbf{T N} \text { water total nitrogen; } \mathbf{T P}=\text { water total phosphorus; } \mathbf{C h l - a}=\text { chlorophyll-a; } \\
\text { Phyto = phytoplankton analysis; } \mathbf{I M M I B}=\text { multimetric index for benthic macroinvertebrates; } \mathbf{C o l}=\text { fecal coliforms; } \\
\text { IM and IA = index of mitosis and index of chromosome alterations based on tests with Allium cepa. } \mathbf{T S I}=\text { trophic } \\
\text { state index. }\end{array}$} \\
\hline
\end{tabular}

to Chaoboridae. The identification was based on the following identification keys: Froehlich (2007), Marchese (2009), Trivinho-Strixino (2011).

A multimetric index was recently suggested as an alternative when aiming to a rapid assessment tool. The index is based on features that can be recognized by trained people but without the requirement of an expertise in taxonomy. The index is based on coarse taxonomic resolution and it was applied to benthic macroinvertebrates assessment.

The final index is the simple mean of seven other index previously standardized to a $0-1$ scale where 1 represent the best condition and 0 the worst. The indexes comprehended in the final multimetric index are mainly based on the ratios between sensitive and tolerant taxa or groups as bloodworms 
chironomids. The taxonomic diversity was also considered as a generic measure of the quality of the environment. This approach was previously suggested for the environmental assessment in the Jundiaí-Mirin basin (Beghelli et al., 2015).

The taxonomic resolution considered here was thought to be achieved without the need of any technique of fixation or lightening. As a result, the identification could be performed by using temporary slides with just water. The groups considered as "tolerants" or "sensitives" were defined by considering previous works performed in tropical environments (Moreno \& Callisto, 2006; Moretti \& Callisto, 2005; Beghelli et al., 2012, 2014b).

Tolerant groups were: bloodworms chironomids (red chironomids); tubificids and Chaoborus sp. Tanytarsinae was considered as a sensitive group. In the current format, the multimetric index is very similar to that suggested for Jundiaí-Mirin basin but it includes the taxon Chaoboridae as a tolerant group and the metric related to exotic species is not considered once that there was no exotic taxons in Itupararanga reservoir. The Hilsenhoff's Family Biotic Index, FBI (Mandaville, 2002) adapted to a $0-1$ scale was also considered. The calculation of the indexes are based on relative abundance (with exception to diversity and FBI).

Density of benthic macroinvertebrates was also calculated by dividing the number of organisms collected by the dredge area.

For genotoxicity test assays with Allium cepa Linnaeus (Amaryllidaceae) were performed according to Dietz \& Herth (2011) and Tedesco $\&$ Laughinghouse (2012).

Seeds of $A$. cepa were germinated until the roots achieve $2 \mathrm{~cm}$. After this procedure, seedlings were transferred to tubes containing the treatments: control, P1 P2, P3, P4 and P5 where remained exposed to the treatments for 24 hours. Then, the roots were fixed in a solution of methanol: acetic acid 3:1 (v/v) for 24h.

Following fixation, the roots were hydrolyzed with an $\mathrm{HCl} 1 \mathrm{M}$ solution at $60 \mathrm{oC}$ for 9 minutes. The material was colored by Schiff's reagent. Slides were mounted by slicing meristematic region of the roots that was fixed by the technique of squashing with aceto carmin. There were mounted three slides per treatment, each of them containing, approximately 500 cells, totaling 1500 per assay from each treatment.

The slides were analyzed under optic microscope (Zeiss Axiovert 60) and the number of cells in division and total of cells per slide was counted for the index of mitosis calculation $(\mathrm{IM}=$ total number of cells in division / total number of counted cells). The number of cells with chromosome alterations - cells with retardatary chromosomes, chromosomes bridges and micronucleus was also counted for index of chromosome alterations calculation (IA $=$ sum of the cells with alterations / total number of cells in division) (Taniwaki et al., 2013).

Considering the data obtained, a matrix with values standardized by $z$ score calculation was produced for 13 variables: Fecal coliforms, suspended solid matter, dissolved matter, Secchi disk lecture, $\mathrm{pH}$, electric conductivity, dissolved oxygen, total nitrogen, total phosphorus, index of mitosis, index of alterations and water temperature. By using $\mathrm{z}$ scores, the variance of each variable is considered as the fluctuations around the respective mean. As consequence, the variation is standardized by this procedure that makes all of them be comparable each other (Triola, 2008). From this standard matrix a Principal Component Analysis (PCA), considering the variances, was performed by using PAST $2.17 \mathrm{c}$ software (Hammer et al., 2001).

\section{Results}

In a general view, the waters from Itupararanga reservoir are alkaline, well oxygenated; it has moderate values of electric conductivity and transparence as also low quantities of suspended matter (Table 2).

The values recorded for $\mathrm{TN}$ were low, below limit of detection in four sampling points. Nevertheless, the concentrations of total phosphorus were high and varied from 270 to $500 \mu \mathrm{g} . \mathrm{L}^{-1}$. By TSI calculations, the Itupararanga reservoir could be classified as in supereutrophic or hypereutrophic conditions (Table 3).

Biological data: The values recorded for fecal coliforms were high. Values were above Brazilian limits for recreational bathing or ingestion (Brasil, 2012) at P1 and P5 (Figure 4).

Table 2. Physico-chemical results.

\begin{tabular}{crrrrr}
\hline Variables $^{1}$ & P1 & P2 & P3 & P4 & \multicolumn{1}{c}{ P5 } \\
\hline T & 18.51 & 18.50 & 19.50 & 19.50 & 19.50 \\
pH & 8.90 & 8.70 & 7.80 & 8.20 & 8.80 \\
EC & 77.00 & 68.00 & 73.00 & 72.00 & 75.00 \\
DO & 12.52 & 12.48 & 9.84 & 11.80 & 9.83 \\
Secchi & 2.91 & 2.16 & 2.02 & 2.25 & 2.51 \\
DM & 21.50 & 42.90 & 30.30 & 25.80 & 32.70 \\
SM & 4.00 & 4.60 & 4.20 & 4.20 & 5.30 \\
\hline
\end{tabular}

${ }^{1} \mathbf{T}=$ temperature $\left({ }^{\circ} \mathrm{C}\right) ; \mathbf{E C}=$ electric conductivity $\left(\mu \mathrm{S} . \mathrm{cm}^{-1}\right)$; $\mathbf{D O}=$ dissolved oxygen $\left(\mathrm{mg} \cdot \mathrm{L}^{-1}\right) ; \mathbf{D M}=$ dissolved matter $\left(\mathrm{mg} . \mathrm{L}^{-1}\right) ; \mathbf{S M}=$ suspended matter $\left(\mathrm{mg} . \mathrm{L}^{-1}\right)$ and Secchi $=$ Secchi disk lecture $(\mathrm{m})$. 
Table 3. Trophic state.

\begin{tabular}{lllllllll}
\hline & TN $^{1}$ & TP $^{2}$ & TN/TP & Chl-a $^{4}$ & TSI $_{\text {Chl }}{ }^{5}$ & TSI $^{{ }^{6}}{ }^{6}$ & TSI $_{\mathbf{m}}{ }^{7}$ & Classification $^{8}$ \\
\hline P1 & 100 & 500 & 0.20 & 23.05 & 62.12 & 72.12 & 67.12 & Hypereutrofic \\
P2 & ND & 410 & ND & 22.45 & 61.99 & 70.92 & 66.45 & Supereutrofic \\
P3 & ND & 390 & ND & 12.83 & 59.24 & 70.62 & 64.93 & Supereutrofic \\
P4 & ND & 480 & ND & 12.83 & 59.24 & 71.87 & 65.56 & Supereutrofic \\
P5 & ND & 270 & ND & 20.72 & 61.59 & 68.39 & 64.99 & Supereutrofic \\
\hline
\end{tabular}

${ }^{1}$ Concentrations of total nitrogen $\left(\mathbf{T N}, \mu \mathrm{g} . \mathrm{L}^{-1}\right) ;{ }^{2}$ total phosphorus $\left(\mathbf{T P}, \mu \mathrm{g} . \mathrm{L}^{-1}\right)$ the ${ }^{3}$ total nitrogen: total phosphorus ratio (TN/TP); ${ }^{4}$ chlorophyll-a concentration (Chl-a, $\left.\mu \mathrm{g} . \mathrm{L}^{-1}\right)$ and the values calculated for the TSI based on ${ }^{5}$ chlorophyll-a - TSI $_{\mathrm{Chl}}-{ }^{6}$ phosphorus - TSI $_{\mathrm{TP}}$ - as also the final mean ${ }^{7} \mathrm{TSI}\left(\mathbf{T S I}_{\mathrm{m}}\right){ }^{8}$ For purposes of classification it is considered: supereutrophic $-63<$ TSI $<67$, hypereutrophic $-67<$ TSI. ${ }^{1,3} \mathrm{ND}$ : are non-detected concentrations that were below limit of detection (see Beghelli et al., 2012; Cunha et al., 2013).

The results of the multimetric index for benthic macroinvertebrates (IMMIB) calculated for the samplings from P1 and P5 points that the environmental quality is below satisfactory condition (Table 4). Density values varied between 495 in $\mathrm{P} 1$ and 1247 ind. $\mathrm{m}^{-2}$ in P5.

The phytoplankton taxonomic class Cyanobacteria was predominant and the dominant species are Cylindrospermopsis raciborskii (Woloszynska) Seenayya and Subba Raju and Monoraphidium contortum (Thuret in Brébisson) Komárkova-Legnerová. (Table 5). The taxa Mycrocistis sp, Dolichospermum sp, Geitlerinema $s p$, Planktolyngbya sp, Planktothrix sp and Pseudoanabaena sp were also present in the samples.

The mean values of the index of chromosome alterations (IA) were about 0.05 and 0.12 . Values were above the control and the most significative differences occurred in samplings with water from P1 and P4. Values of index of mitosis (IM) were distinguishable from control only in the samplings treated with P3 water where highly IM was recorded. P1 and P4 presented mean values below control but with high variation. This can be interpreted as indicating a beginning genotoxicity (Figure 5).

Principal Components Analysis (PCA) shows that the variables considered in this study could explain $69.77 \%$ of the observed variation. From this, $41.10 \%$ refers to component $1(\mathrm{C} 1)$ and $28.67 \%$ to the component 2 (C2) (Figure 6). Table 6 presents $r$ values in relation to the first three components.

\section{Discussion}

Our results corroborate the hypothesis that it is possible to get sufficient information for monitoring based in on sampling campaign but considering distinct predictors. When comparing
Table 4. Multimetric index based on benthic macroinvertebrates community - IMMIB.

\begin{tabular}{lcc}
\hline \multicolumn{1}{c}{ Indices / metrics } & P1 & P5 \\
\hline Diversity & 0.66 & 0.62 \\
\hline 1 - $(0.1 \times \mathrm{FBI})$ & 0.36 & 0.23 \\
\hline 1 - \% tolerants & \\
\hline $\begin{array}{l}\text { Tanytarsini / } \\
\text { Chironomidae }\end{array}$ & 0.78 & 0.21 \\
\hline $\begin{array}{l}\text { 1-(red Chironominae/ } \\
\text { sum of Chironomidae) }\end{array}$ & 0.20 & 0.20 \\
\hline 1- \%Tubificinae & 0.21 & 0.50 \\
\hline IMMB (mean) & 1.00 & 0.99 \\
\hline Classification & 0.53 & 0.46 \\
\hline
\end{tabular}

Values in a 0-1 scale. Organisms considered as "tolerants". ${ }^{1}$ were Chaoborus sp, red Chironominae and Tubificinae. ${ }^{2}$ Final classification varies between seven categories. As IMMB is nearer of 1 , better is the water / sediment quality.

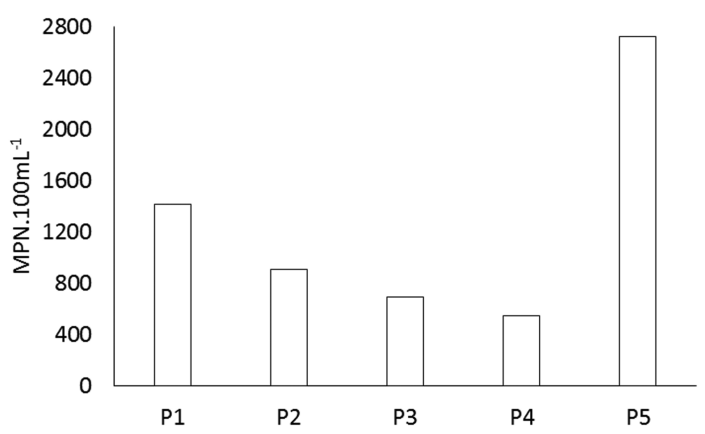

Figure 4. Fecal coliforms density.

the results with satellite imagery it is clear that the most impacted areas (P1, P4 and P5) had poorer conditions.

Furthermore, the predictors presented agreement or complementarity between them, but not disagreements. The present results corroborate in the sense that P1 and P5 are impaired. These sampling points were in eutrophic or supereutrophic 
Table 5. Phytoplankton community.

\begin{tabular}{|c|c|c|c|c|}
\hline \multirow{2}{*}{ Classes } & \multicolumn{2}{|c|}{ Density $^{1}$} & \multicolumn{2}{|c|}{$\mathrm{RA}^{2}$} \\
\hline & P1 & P5 & P1 & P5 \\
\hline Bacillariophyceae & 255 & 450 & 0.92 & 1.84 \\
\hline Oedogoniophyceae & 227 & 50 & 0.82 & 0.20 \\
\hline Cyanobacteria & 21747 & 18089 & 78.85 & 73.87 \\
\hline Chlorophyceae & 4757 & 4997 & 17.25 & 20.41 \\
\hline Dinophyceae & 453 & 800 & 1.64 & 3.27 \\
\hline Euglenophyceae & 142 & 100 & 0.51 & 0.41 \\
\hline Total & 27581 & 24486 & 100.00 & 100.00 \\
\hline
\end{tabular}

Qualitative and quantitative data about phytoplankton communities from P1 and P5 in Itupararanga reservoir.

${ }^{1}$ Densities in ind. $\mathrm{L}^{-1} ;{ }^{2}$ relative abundance (RA) in percentage.
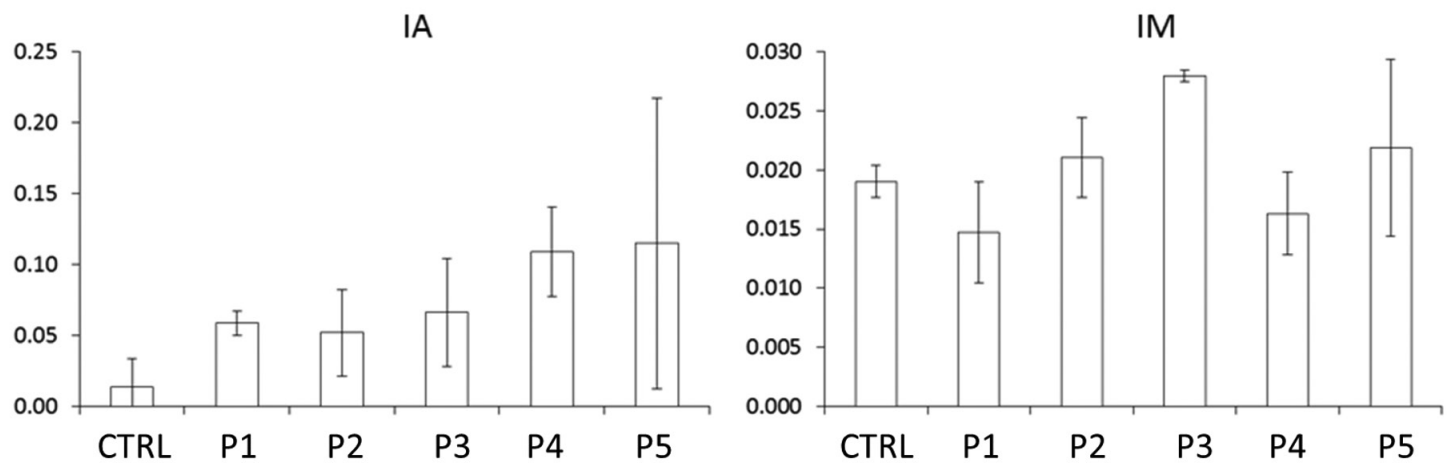

Figure 5. Index of chromosome alterations (IA) and index of mitosis (IM). Samplings with $A$. cepa treated with waters from P1, P2, P3, P4 and P5 and a control.

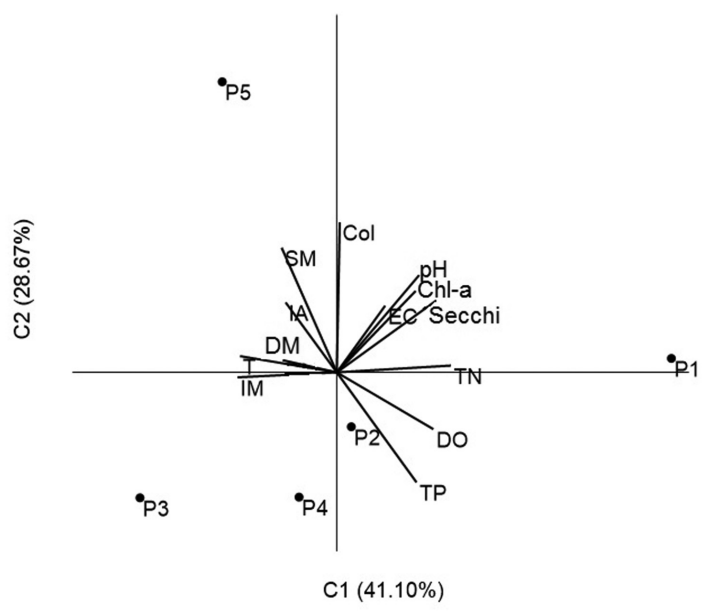

Figure 6. PCA analysis. Variables considered: index of mitosis, temperature, dissolved matter (DM); index of chromosome alterations, suspended matter, fecal coliforms (Col); electric conductivity (EC); $\mathrm{pH}$, chlorophylla concentration (Chl-a); Secchi disk lecture (Secchi); total nitrogen (TN); dissolved oxygen (DO) and total phosphorus (TP).

conditions, with high coliform densities and proportion of cyanobacteria. Furthermore, both were classified as "impaired" considering the benthic macroinvertebrates. Sampling points P4 and P5 presented high toxicity what is expected in areas with high degree of urbanization (Siegler et al., 2016). There is no results pointing to worst conditions in P2 or P3 when compared with sampling points $\mathrm{P} 1$ and $\mathrm{P} 5$.

Of course that the more replicates are considered in a given analysis of the environment, more strong will be the evidences (Logan, 2010). Despite of that, our work demonstrated that when using distinct sources of data a realistic and rapid assessment can be achieved based on the weight of evidence.

The P1 can be characterized by high nitrogen and chlorophyll-a values and it is also the sampling point that is in a more eutrophic condition despite the important contribution that the reservoir receives from the former rivers (Beghelli et al., 2012). This situation can be interpreted as a consequence of the nitrogen availability that clearly is the limiting factor for the phytoplankton in the reservoir considering the period analyzed. Beghelli et al. (2016) also recorded limitation by nitrogen in the reservoir.

Transport of nutrients and phytoplankton by waterflow must be also considered. However, in this case, it would be expected higher trophic state in the intermediary section of the reservoir, which 
Table 6. Correlation ( $\mathrm{r}$ ) between variables and PCA components $\mathrm{C} 1, \mathrm{C} 2$ and $\mathrm{C} 3$.

\begin{tabular}{crrr}
\hline & C1 & C2 & \multicolumn{1}{c}{ C3 } \\
\hline T & -0.78 & 0.11 & 0.60 \\
pH & 0.66 & 0.64 & -0.34 \\
EC & 0.39 & 0.44 & 0.74 \\
DO & 0.78 & -0.38 & -0.36 \\
Secchi & 0.82 & 0.49 & 0.28 \\
DS & -0.44 & 0.08 & -0.90 \\
SS & -0.44 & 0.83 & -0.30 \\
Col & 0.02 & 1.00 & 0.04 \\
IM & -0.80 & -0.03 & -0.16 \\
IA & -0.41 & 0.46 & 0.51 \\
TN & 0.92 & 0.05 & 0.25 \\
TP & 0.64 & -0.73 & 0.18 \\
Chl-a & 0.64 & 0.54 & -0.54 \\
\hline
\end{tabular}

means P2, P3, P4 and P5, according to the theory of Thornton et al. (1982). As consequence, we believe that the main driver of trophic state in the reservoir, considering transitional and lacustrine zones, are land uses. In this case, P1 must receive allochthonous phosphorus and nitrogen from cattle ranching (Giraldo et al., 2014) or eucalyptus crops (Oyarzun et al., 2007).

Sampling point P5 is surrounded by urbanized area. Despite its lowest phosphorus concentrations, P1 chlorophyll-a concentrations was higher than in $\mathrm{P} 2$ or $\mathrm{P} 3$. This situation reinforces the assertion that phosphorus concentrations are not limiting the phytoplankton growth. From this data, it can be also concluded that the phosphorus inputs in studied area are mainly originated from eucalyptus plantation, pasture (P1) and agriculture practices (P2 and P3). Despite some variation, in general, TP, Chl-a and coliforms presents an increasing pattern from P4 to P1 that can be related to water flow gradient. The increasing pattern must indicate a cumulative TP and coliforms inputs in dam direction. Waters coming from the Ressaca branch that receives waters from a stream with the same name comes from an area that receives multiple anthropic impacts (Cunha \& Calijuri, 2011) and may be related to the distinctly high TP value recorded on $\mathrm{P} 4$.

Considering the fecal coliforms analyses, $\mathrm{P} 1$ and P5 presented the highest concentrations and these results are in disagreement with national legislation (Brasil, 2012). When considering a more preventive analysis, the entire reservoir could be considered with waters inappropriate for bath or drinking (Lévesque \& Gauvin, 2007). We believe that the main coliforms source is in the area surrounding P5 with domestic sewage discharges originated from the urbanized area. A second important contribution must occur in P1 area coming from pasture activities.

Benthic macroinvertebrates analysis indicate that both, the area dominated by eucalyptus plantation and pasture and the most urbanized area are in bad conditions. The final value of index suggests that P5 is in a worst condition in agreement with data from coliforms analysis and genotoxicity index of chromosome alterations. These results points that IMMIB is an index that is more sensible to anthropogenic impacts proceeding from urbanized areas than those related to nutrient inputs. The higher density recorded at P5 may be a response to organic matter accumulation in the sediments (Beghelli et al., 2014b).

The predominance of Cyanobacteria in $\mathrm{P} 1$ and P5 is a worrying scenario. The identified taxa are potentially toxin producers (Vasconcelos et al., 2011). C. raciborskii can synthesize saxitoxin and cylindrospermopsin. In general, its predominance in phytoplankton are related to some characteristics of the species as phosphorus affinity (Bouvy et al., 2000; Posselt et al., 2009), low luminosity tolerance, ammonium affinity (Tucci \& Sant'anna, 2011), resistance to predation (Panosso et al., 2003), and high phenotypic plasticity (Bonilla et al., 2012).

When compared with previous research in the same reservoir (Cunha \& Calijuri, 2011) our phytoplankton data suggest to the increment of Cyanobacteria dominance in the reservoir. In this scenario, the risks of water contamination by cyanotoxins are progressively higher representing risks for human health. The results from genotoxicity tests reinforce the scenario that consider the presence of toxicants in the waters from Itupararanga.

Considering the results of the index of chromosome alterations it is clear that there is some substance in the waters that are toxic enough to result in chromosome alterations in A. cepa. High values for genotoxicity are related to the urbanized area (P4 and P5) suggesting that the main source of contamination is located there and associated with this land use. Furthermore, is important to highlight that the data suggest that the other sampling stations are also contaminated.

The data obtained by a one-sampling campaign showed complementarity and coherence with each other and with the land uses. In a broad view, the distinct indicators considered here demonstrate a bad water quality condition in the reservoir with the intermediary sampling points (P2 and P3), where higher proportions of natural vegetation 
were observed, presenting better results. Urbanized areas (P4 and $\mathrm{P} 5)$ were most related to toxicity and the sampling points P1 and P5 was in the worst conditions. The influence of water flow was also determinant of water quality along reservoir.

These results corroborates our hypothesis that a one-sampling campaign can provide robust information for monitoring purposes when different kinds of indicators are used and compared. Despite of this the consideration of the seasonality dynamics is also recommended once it can act by intensifying or soothe the environmental condition temporally, but it is usually not so strong to alter the conclusions about the general situation of an ecosystem (Beghelli et al., 2012).

\section{Conclusions}

We conclude that the comprehensive and rapid approach used here, based in one-sampling campaign with distinct environmental indicators, was effective to take a diagnostic about Itupararanga reservoir environmental quality. The reservoir presents two main sources of anthropic impacts clearly related to the land uses: eutrophication promoted by phosphorus inputs related to rural uses and the presence of toxic substances related to the urbanized area. The predominance of Cyanobacteria is a worrying situation and could be related to the observed toxicity. The IMMB index reinforce the poor environmental quality of the reservoir.

\section{Acknowledgements}

The authors thank FAPESP (2013/03494-4; 2013/08272-0; 2012/11890-4) for financial support.

\section{References}

AMERICAN PUBLIC HEALTH ASSOCIATION - APHA. Standard methods for the examination of water and wastewater. 21st ed. Washington, DC: APHA, 2005.

BEGHELLI, F.G.S., CARVALHO, M.E.K., PECHE FILHO, A., MACHADO, F.H., MOSCHINICARLOS, V., POMPÊO, M., RIBEIRO, A.I. and MEDEIROS, G.A. Uso do índice de estado trófico e análise rápida da comunidade de macroinvertebrados como indicadores da qualidade ambiental das águas na Bacia do Rio Jundiaí-Mirim - SP - BR. Brazilian Journal of Aquatic Science and Technology, 2015, 19(1), 13-22. http://dx.doi.org/10.14210/bjast. v19n1.p13-22.

BEGHELLI, F.G.S., FRASCARELI, D., POMPÊO, M.L.M. and MOSCHINI-CARLOS, V. Trophic state evolution over 15 years in a Tropical reservoir with low nitrogen concentrations and cyanobacteria predominance. Water, Air, and Soil Pollution, 2016, 227(3), 95-110. http://dx.doi.org/10.1007/s11270016-2795-1.

BEGHELLI, F.G.S., POMPÊO, M.L.M. and MOSCHINI-CARLOS, V. First occurrence of the exotic Asian clam Corbicula fluminea (Muller, 1774) in the Jundiaí-Mirim River Basin, SP, Brazil. Ambiente e Água, 2014a, 9, 402-408.

BEGHELLI, F.G.S., SANTOS, A.C.A., URSOGUIMARÁES, M.V. and CALIJURI, M.C. Relationship between space distribution of the benthic macroinvertebrates community and trophic state in a Neotropical reservoir (Itupararanga, Brazil). Biota Neotropica, 2012, 12(4), 114-124. http:// dx.doi.org/10.1590/S1676-06032012000400012.

BEGHELLI, F.G.S., SANTOS, A.C.A., URSOGUIMARÁES, M.V. and CALIJURI, M.C. Spatial and temporal heterogeneity in a subtropical reservoir and their effects over the benthic macroinvertebrate community. Acta Limnologica Brasiliensia, 2014b, 26, 306-317.

BENEDETTI, M., CIAPRINI, F., PIVA, F., ONORATI, F., FATTORINI, D., NOTTI, A., AUSILI, A. and REGOLI, F. A multidisciplinary weight of evidence approach for classifying polluted sediments: Integrating sediment chemistry, bioavailability, biomarkers responses and bioassays. Environment International, 2012, 38(1), 17-28. http://dx.doi.org/10.1016/j.envint.2011.08.003. PMid:21982029.

BICUDO, C.E.M. and MENEZES, M. Gêneros de algas de águas continentais do Brasil: chave para identificação e descriçôes. São Carlos: Rima, 2006, 502 p.

BONADA, N., PRAT, N., RESH, V.H. and STATZNER, B. Developments in aquatic insect biomonitoring: a comparative analysis of recent approaches. Annual Review of Entomology, 2006, 51(1), 495-523. http://dx.doi.org/10.1146/annurev. ento.51.110104.151124. PMid:16332221.

BONILLA, S., AUBRIOT, L., SOARES, M.C.S., GONZÁLEZ-PIANA, M., FABRE, A., HUSZAR, V.L.M., LÜRLING, M., ANTONIADES, D., PADISÁK, J. and KRUK, C. What drives the distribution of the bloom-forming cyanobacteria Planktothrix agardhii and Cylindrospermopsis raciborskii? FEMS Microbiology Ecology, 2012, 79(3), 594-607. http://dx.doi.org/10.1111/j.15746941.2011.01242.x. PMid:22092489.

BOUVY, M., FALCÁO, D., MARINHO, M., PAGANO, M. and MOURA, A. Occurrence of Cylindrospermopsis (Cyanobacteria) in 39 Brazilian tropical reservoirs during the 1998 drought. Aquatic Microbial Ecology, 2000, 23, 13-27. http://dx.doi. org/10.3354/ame023013.

BRANDT, M., BECKER, E., JÖHNCKE, U., SÄTTLER, D. and SCHULTE, C. A weight-ofevidence approach to assess chemicals: case study on the assessment of persistence of 4,6-substituted 
phenolic benzotriazoles in the environment. Environmental Sciences Europe, 2016, 28(1), 4-17. http://dx.doi.org/10.1186/s12302-016-0072-y.

BRASIL. Ministério do Meio Ambiente - MMA. Conselho Nacional do Meio Ambiente - CONAMA. Resoluçôes do Conama: resoluçôes vigentes publicadas entre Setembro de 1984 e Janeiro de 2012. Brasília: MMA, 2012.

CARDOSO-SILVA, S., FERREIRA, P.A.L., MOSCHINI-CARLOS, V., FIGUEIRA, R.C.L. and POMPEO, M. Temporal and spatial accumulation of heavy metals in the sediments at Paiva Castro Reservoir (São Paulo, Brazil). Environmental Earth Sciences, 2016, 75(1), 9-25. http://dx.doi. org/10.1007/s12665-015-4828-2.

CUNHA, D.G.F. and CALIJURI, M.C. Variação sazonal dos grupos funcionais fitoplanctônicos em braços de um reservatório tropical de usos múltiplos no estado de São Paulo (Brasil). Acta Botanica Brasílica, 2011, 25, 822-831. http://dx.doi.org/10.1590/S010233062011000400009 .

CUNHA, D.G.F., CALIJURI, M.C., LAMPARELLI, M.C. and MENEGON JUNIOR, N. Resolução CONAMA 357/2005: análise espacial e temporal de não conformidades em rios e reservatórios do estado de São Paulo de acordo com seus enquadramentos (2005-2009). Engenharia Sanitária e Ambiental, 2013, 18(2), 159-168. http://dx.doi.org/10.1590/ S1413-41522013000200008.

DI VEROLI, A., SANTORO, F., PALLOTTINI, M., SELVAGGI, R., SCARDAZZA, F., CAPPELLETTI, D. and GORETTI, E. Deformities of chironomid larvae and heavy metal pollution: from laboratory to field studies. Chemosphere, 2014, 112, 9-17. http:// dx.doi.org/10.1016/j.chemosphere.2014.03.053. PMid:25048882.

DÍAZ-BARRIGA, S., MARTÍNEZ-TABCHE, L., ÁLVAREZ-GONZÁLEZ, I., LÓPEZ, E.L. and MADRIGAL-BUJAIDAR, E. Toxicity induced by dieldrin and chlorpyrifos in the freshwater crayfish Cambarellus montezumae (Cambaridae). Revista de Biologia Tropical, 2015, 63(1), 83-96. http://dx.doi. org/10.15517/rbt.v63i1.13665. PMid:26299117.

DIETZ, K.J. and HERTH, S. Plant nanotoxicology. Trends in Plant Science, 2011, 16(11), 582-589. http://dx.doi.org/10.1016/j.tplants.2011.08.003. PMid:21906987.

DUARTE, A.C.R. and BORGES, J.C.S. Resultados preliminares do efeito da água da represa Billings na tireóide das tilápias. Atas de Saúde Ambiental, 2016, 3, 10-16.

ESTEVES, F.A. Fundamentos de Limnologia. Rio de Janeiro: Interciência, 2011, 826 p.

ESTEVES, K.E., LÔBO, A.V.P. and HILSDORF, W.F. Abiotic features of a river from the Upper Tietê River Basin (SP, Brazil) along an environmental gradient. Acta Limnologica Brasiliensia, 2015, 27(2), 228-237. http://dx.doi.org/10.1590/S2179-975X5914.
FERNANDEZ, M.A., MATTOS, A.C., SILVA, E.F., SANTOS, S.B. and THIENGO, S.C. A malacological survey in the Manso Power Plant, State of Mato Grosso, Brazil: new records of freshwater snails, including transmitters of schistosomiasis and exotic species. Revista da Sociedade Brasileira de Medicina Tropical, 2014, 47(4), 498-506. http://dx.doi.org/10.1590/0037-8682-0138-2014. PMid:25229292.

FONTANA, L., ALBUQUERQUE, A.L.S., BRENNER, M., BONOTTO, D.M., SABARIS, T.P.P., PIRES, M.A.F., COTRIM, M.E.B. and BICUDO, D.C. The eutrophication history of a tropical water supply reservoir in Brazil. Journal of Paleolimnology, 2014, 51(1), 29-43. http://dx.doi.org/10.1007/s10933013-9753-3.

FREITAS, N.P., GARCIA, J.P.M., KAWAKUBO, F.S., LUCHIARI, A., SILVA FILHO, N.L., ARGOUD, L., MORATO, R.G., PEÇANHA, M.P. and TAKAKI, M. Sistema de informaçóes ambientais da bacia hidrográfica da represa de Itupararanga como suporte à implantação de uma área de proteçáo ambiental no estado de São Paulo. Geografia and Pesquisa, 2008, 2, 17-32.

FROEHLICH, C.G., org. Guia on-line: identificação de larvas de insetos aquáticos do Estado de Sáo Paulo [online]. Ribeirão Preto: USP, 2007 [viewed 01 Jan. 2016]. Available from: http://sites.ffclrp.usp.br/ aguadoce/guiaonline

GIRALDO, L.P., CHARÁ, J., ZUÑIGA, M.C., CHARÁ-SEMA, A.M. and PEDRAZA, G. Impacto del uso del suelo agropecuario sobre macroinvertebrados acuáticos en pequeñas quebradas de la cuenca del río La Vieja (Valle del Cauca, Colombia). Revista de Biologia Tropical, 2014, 62(Suppl 2), 203-209. http://dx.doi.org/10.15517/ rbt.v62i0.15788. PMid:25189079.

HAMMER, O., HARPER, D.A.T. and RYAN, P.D. PAST: Paleontological statistics software package for education and data analysis. Paleontologia Electronica, 2001, 4(1), 9.

JONGH, C.M., KOOIJ, P.J.F., VOOGT, P. and LAAK, T.L. Screening and human health risk assessment of pharmaceuticals and their transformation products in Dutch surface waters and drinking water. The Science of the Total Environment, 2012, 427-428, 70-77. http://dx.doi.org/10.1016/j.scitotenv.2012.04.010. PMid:22551934.

LÉVESQUE, B. and GAUVIN, D. Microbiological guideline values for recreational bathing in Canada: time for change? Canadian Journal of Infectious Diseases and Medical Microbiology, 2007, 18(2), 153-157. http://dx.doi.org/10.1155/2007/180308. PMid:18923764.

LOGAN, M. Biostatistical design and analysis using $R$ : a practical guide. Oxford: Wiley Blackwell, 2010, 577 p.

LOWELL, R.B., CULP, J.M. and DUBÉ, M.G. A weight-of-evidence approach for northern river 
risk assessment: Integrating the effects of multiple stressors. Environmental Toxicology and Chemistry, 2000, 4(4), 1182-1190. http://dx.doi.org/10.1002/ etc. 5620190452 .

MACEDA-VEIGA, A., MONROY, M., NAVARRO, E., VISCOR, G. and SOSTOA, A. Metal concentrations and pathological responses of wild native fish exposed to sewage discharge in a Mediterranean river. The Science of the Total Environment, 2013, 449, 9-19. http://dx.doi.org/10.1016/j.scitotenv.2013.01.012. PMid:23403098.

MANDAVILLE, S.M. Benthic macroinvertebrates in freshwaters: taxa tolerance values, metrics and protocols. Soil \& Water Conservation Society of Metro Halifax, 2002, 125 p.

MANFRÉ, L.A., SILVA, A.M. and URBAN, R.C. Atributos de qualidade de solos sob dois diferentes tipos de manejo no município de Ibiúna-SP, Brasil. Interciencia, 2011, 36, 757-763.

MARCHESE, M.R. Macroinvertebrados bentónicos sudamericanos. In E. DOMÍNGUEZ and H. E. FERNÁNDEZ, eds. Sistemática y biología. Tucumán: Fundación Miguel Lillo, 2009, pp. 551-565.

MARTINS, M.N.C., SOUZA, V.V. and SOUZA, T.S. Cytotoxic, genotoxic and mutagenic effects of sewage sludge on Allium cepa. Chemosphere, 2016, 148, 481-486. http://dx.doi.org/10.1016/j. chemosphere.2016.01.071. PMid:26841290.

MORENO, P. and CALLISTO, M. Benthic macroinvertebrates in the watershed of an urban reservoir in southeastern Brazil. Hydrobiologia, 2006, 560(1), 311-321. http://dx.doi.org/10.1007/s10750005-0869-y.

MORETTI, M.L. and CALLISTO, M. Biomonitoring of benthic macroinvertebrates in the middle Doce River watershed. Acta Limnologica Brasiliensia, 2005, 17, 267-281.

MOSCHINI-CARLOS, V., POMPÊO, M. L. M. and FREITAS, L. Limnological evaluation of water in the Rio Grande and Taquacetuba branches of the Billings Complex (São Paulo, Brazil) and management implications. Revista Ambiente and Água: An Interdisciplinary Journal of Applied Science, 2010, 5, 77-89.

MUNIZ, D.H.F., MORAES, A.S., FREIRE, I.S., CRUZ, C.J.D., LIMA, J.E.F.W. and OLIVEIRAFILHO, E.C. Evaluation of water quality parameters for monitoring natural, urban, and agricultural areas in the Brazilian Cerrado. Acta Limnologica Brasiliensia, 2011, 23(3), 307-317. http://dx.doi. org/10.1590/S2179-975X2012005000009.

NI, Z., WANG, S., XU, Z. and JIN, X. Historical accumulation of $\mathrm{N}$ and $\mathrm{P}$ and sources of organic matter and $\mathrm{N}$ in sediment in an agricultural reservoir in Northern China. Environmental Science and Pollution Research International, 2015, 22(13), 9951 9964. http://dx.doi.org/10.1007/s11356-015-41694. PMid:25663341.
OYARZUN, C., ARACENA, C., RUTHERFORD, P., GODOY, R. and DESCHRIJVER, A. Effects of land use conversion from native forests to exotic plantations on nitrogen and phosphorus retention in catchments of Southern Chile. Water, Air, and Soil Pollution, 2007, 179(1-4), 341-350. http://dx.doi. org/10.1007/s11270-006-9237-4

PANOSSO, R., CARLSON, P., KOZLOWSKYSUZUKI, B., AZEVEDO, S.M.F.O. and GRANÉLI, E. Effect of grazing by a Neotropical copepod, Notodiaptomus, on a natural cyanobacterial assemblage and on toxic and non-toxic cyanobacterial strains. Journal of Plankton Research, 2003, 25(9), 1169-1175. http://dx.doi.org/10.1093/ plankt/25.9.1169.

PARANHOS, R. Alguns métodos para análise da água. Rio de Janeiro: Cadernos Didáticos, 1996, 281 p.

POMPÊO, M., PADIAL, P.R., MARIANI, C.F., CARDOSO-SILVA, S., MOSCHINI-CARLOS, V., SILVA, D.C.V.R., PAIVA, T.C.B. and BRANDIMARTE, A.L. Ecological risk index for aquatic pollution control: a case study of coastal water bodies from the Rio de Janeiro State, southeastern Brazi. Geochimica Brasiliensis, 2013, 27(2), 104-119. http://dx.doi.org/10.5327/Z01029800201300020003.

POSSELT, A.J., BURFORD, M.A. and SHAW, G. Pulses of phosphate promote dominance of the toxic cyanophyte Cylindrospermopsis raciborskii in a subtropical water reservoir. Journal of Phycology, 2009, 45(3), 540-546. http://dx.doi.org/10.1111/ j.1529-8817.2009.00675.x. PMid:27034030.

RIETZLER, A.C., MAIA-BARBOSA, P.M., RIBEIRO, M.M. and MENENDEZ, R.M. On the first record of the exotic Moina macrocopa (Straus, 1820) in Minas Gerais State, Brazil. Brazilian Journal of Biology = Revista Brasileira de Biologia, 2014, 74(2), 518520. http://dx.doi.org/10.1590/1519-6984.14113. PMid:25166341

SANT'ANNA, C.L., AZEVEDO, M.T.P., AGUJARO, L.F., CARVALHO, M.C., CARVALHO, L.R. and SOUZA, R.C.R. Manual ilustrado para identificação e contagem de cianobactérias planctônicas de águas continentais brasileiras. Rio de Janeiro: Interciência, 2006, $58 \mathrm{p}$.

SIEGLER, K., PHILLIPS, B.M., ANDERSON, B.S., VOORHEES, J.P. and TJEERDEMA, R.S. Temporal and spatial trends in sediment contaminants associated with toxicity in California watersheds. Environmental Pollution, 2016, 206, 1-6. http://dx.doi.org/10.1016/j.envpol.2015.06.028. PMid:26141126.

SILVA, A.P.C. and COSTA, I.A.S. Biomonitoring ecological status of two reservoirs of the Brazilian semi-arid using phytoplankton assemblages ( $Q$ index). Acta Limnologica Brasiliensia, 2015, 25(1), 1-14. http://dx.doi.org/10.1590/S2179-975X2014. 
SINGLETON, B., TURNER, J., WALTER, L., LATHAN, N., THORPE, D., OGBEVOEN, P., DAYE, J., ALCORN, D., WILSON, S., SEMIEN, J., RICHARD, T., JOHNSON, T., MCCABE, K., ESTRADA, J.J., GALVEZ, F., VELASCO, C. and REISS, K. Environmental stress in the Gulf of Mexico and its potential impact on public health. Environmental Research, 2016, 146, 108-115. http://dx.doi.org/10.1016/j.envres.2015.12.019. PMid:26745734.

SMITH, W.S., SALMAZZI, B.A., POSSOMATO, H.M., OLIVEIRA, L.C.A., ALMEIDA, M.A.G., PUPO, R.H. and TAVARES, T.A. A bacia do rio Sorocaba: caracterização e principais impactos. Revista Cientifica do IMAPES, 2005, 3, 110-113.

SURIANO, M.T. and FONSECA-GESSNER, A.A. Structure of benthic macroinvertebrate assemblages on a gradient of environmental integrity in Neotropical streams. Acta Limnologica Brasiliensia, 2013, 25(4), 418-428. http://dx.doi.org/10.1590/ S2179-975X2013000400007.

TANIWAKI, R.H., ROSA, A.H., LIMA, R., MARUYAMA, C.R., SECCHIN, L.F., CALIJURI, M.C. and MOSCHINI-CARLOS, V. A influência do uso e ocupação do solo na qualidade e genotoxicidade da água no reservatório de Itupararanga, São Paulo, Brasil. Interciencia, 2013, 38, 164-170.

TEDESCO, S.B. and LAUGHINGHOUSE, H.D. Bioindicator of genotoxicity: the Allium cepa test. Environmental Contamination, 2012, 1, 137.

TESTAI, E., SCARDALA, S., VICHI, S., BURATTIA, F.M. and FUNARIA, E. Risk to human health associated with the environmental occurrence of cyanobacterial neurotoxic alkaloids anatoxins and saxitoxins. Critical Reviews in Toxicology, 2016, 46(5), 385-419. http://dx.doi.org/10.3109/10408444.201 5.1137865. PMid:26923223.

THORNTON, K.W., KENNEDY, R.H., MAGOUN, A.D. and SAUL, G.E. Reservoir water quality sampling design. Journal of the American Water Resources Association, 1982, 18(3), 471-478. http:// dx.doi.org/10.1111/j.1752-1688.1982.tb00014.x.

TORRES, P.J. and RAMÍREZ, A. Land use effects on leaf litter breakdown in low-order streams draining a rapidly developing tropical watershed in Puerto Rico. Revista de Biologia Tropical, 2014, 62(Suppl 2), 129 142. http://dx.doi.org/10.15517/rbt.v62i0.15783. PMid:25189074.

TRINDADE, P.B.C.B. and MENDONÇA, A.S.F. Eutrofização em reservatórios: estudo de caso: reservatório de Rio Bonito (ES). Engenharia Sanitária e Ambiental, 2014, 19(3), 275-282. http://dx.doi. org/10.1590/S1413-41522014019000000537.

TRIOLA, M.F. Introdução à estatística. Rio de Janeiro: LTC, 2008.

TRIVINHO-STRIXINO, S. Larvas de Chironomidae: guia de identificação. São Carlos: Gráfica da Universidade Federal de São Carlos, 2011, 371 p.

TUCCI, A. and SANT'ANNA, C. L. Cylindrospermopsis raciborskii (Woloszynska) Seenayya and Subba Raju (Cyanobacteria): weekly variation and relation with environmental factors in an eutrophic lake, São Paulo, SP, Brazil. Brazilian Journal of Botany, 2011, 26, 97-112.

UTERMÖHL, H. Zur Vervollkomnung der quantitativen Phytoplankton-Methodik. Mitteilung Internationale Vereinigung fuer Theoretische unde Amgewandte Limnologie, 1958, 9, 1-38.

VASCONCELOS, J.F., BARBOSA, J.E.L., DINIZ, C.R. and CEBALLOS, B.S.O. Cianobactérias em reservatórios do Estado da Paraíba: ocorrência, toxicidade e fatores reguladores. Boletim da Sociedade Brasileira de Limnologia, 2011, 39, 1-20.

VASCONCELOS, V.M. Global changes and the new challenges in the research on cyanotoxin risk evaluation. Limnética, 2015, 34, 149-158.

WETZEL, R.G. and LIKENS, G.E. Limnological analysis. 2nd ed. New York: W. B. Saunders Company, 1991, 391 p.

WINKLER, L.W. Die Bestimmung des im Wasser gelosten Sauerstoffes. Chemische Berichte, 1888, 21, 2843-2855.

WONGSASULUK, P., CHOTPANTARAT, S., SIRIWONG, W. and ROBSON, M. Heavy metal contamination and human health risk assessment in drinking water from shallow groundwater wells in an agricultural area in Ubon Ratchathani province, Thailand. Environmental Geochemistry and Health, 2014, 36(1), 169-182. http://dx.doi.org/10.1007/ s10653-013-9537-8. PMid:23771812.

ZELNÍČKOVÁ, L., SVOBODOVÁ, Z., MARŠÁLEK, P. and DOBŠÍKOVÁ, R. Persistent organic pollutants in muscle of fish collected from the Nové Mlýny reservoir in Southern Moravia, Czech Republic. Environmental Monitoring and Assessment, 2015, 187(7), 448-454. http://dx.doi.org/10.1007/s10661015-4460-3. PMid:26092236.

Received: 13 November 2015 Accepted: 17 May 2016 